\title{
Tujuan Pembangungan Berkelanjutan (TPB): Hilirisasi Inovasi Teknologi Informasi dan Komunikasi menuju Independent dan Smart Village
}

\author{
Gede Eka Putrawan ${ }^{1}$, Bambang Riadi ${ }^{2}$ Ryzal Perdana ${ }^{3}$ \\ ${ }^{1}$ English education, Lampung University, Bandar Lampung, 35145, Lampung, Indonesia \\ ${ }^{2}$ Indonesian language education, Lampung University, Bandar Lampung, 35145, Lampung, Indonesia, \\ ${ }^{3}$ Primary school teacher education, Lampung University, Bandar Lampung, 35145, Lampung, Indonesia
}

\begin{abstract}
.
Menuju desa independent dan smart yang berjaya, maju, dan mandiri, serta sejahtera, bentuk partisipasi aktif dari berbagai pihak, termasuk universitas, untuk mendukung ketercapaian program tersebut sangat dibutuhkan. Oleh karena itu, kegiatan pengabdian kepada masyarakat ini akan dilakukan dalam rangka hilirisasi inovasi teknologi informasi dan komunikasi untuk menuju independent dan smart village ini yang akan dilaksanakan di Desa Rukti Endah Kecamatan Seputih Raman Kabupaten Lampung Tengah. Tujuan kegiatan ini adalah untuk mengadakan laman resmi desa, melatih sumber daya manusia, dan melakukan digitalisasi data dan informasi serta pelayananan publik. Kegiatan ini akan dilakukan dengan metode presentasi, diskusi, pengembangan model, praktik, dan simulasi. Melalui kegiatan ini, diharapkan desa mitra akan mampu meningkatkan kualitas layanan sehingga tidak lagi membingungkan dan menyita waktu sehingga aparatur desa tidak akan sibuk dengan masalah administrasi. Selain itu, data dan informasi desa akan lebih terorganisir sehingga pengambilan keputusan untuk tujuan pembangunan berbasis data dapat dilakukan secara tepat serta berbagai potensi desa akan bisa diakses oleh siapapun dan kapanpun. Desa digital progres untuk kedepannya sangat baik karena dengan adanya smart village diharapkan desa dapat menjadi mandiri dan mampu menjalankannya. Struktur desa juga penting karena menjadikan masyarakat sebagai bagian penting dari pembangunan dan kemajuan desa sehingga hampir semua kebijakan desa akan selalu memperhatikan keberadaan masyarakat.
\end{abstract}

Keywords.

desa mandiri, desa digital, smart village, inovasi teknologi, desa berjaya

\section{PENDAHULUAN}

Program Smart Village merupakan upaya pemerintah provinsi Lampung untuk membantu masyarakat meningkatkan literasi internet, layanan perpustakaan digital, digitalisasi data dan administrasi desa, serta e-participation dan ini merupakan upaya nyata pemerintah

\section{* Corresponding author: gputrawan08@fkip.unila.ac.id}

Received 8 October 2021; Received in revised form 20 October 2021; Accepted 20 October 2021 
provinsi dalam memenuhi salah satu janji kerja Gubernur Lampung Periode 2019 - 2024 untuk mewujudkan misi yang kedua yaitu 'good governance' dengan harapan upaya nyata ini mampu memberikan manfaat pemerataan dan pelayanan publik yang berkualitas bagi masyarakat [1] sehingga Pemerintah Provinsi Lampung mampu meraih visinya yaitu "Rakyat Lampung Berjaya: Aman Berbudaya Maju Berdayasaing dan Sejahtera" [2]. Selain itu, program ini tentu sejalan juga dengan program pemerintah 'Making Indonesia 4.0' yang diinisiasi oleh Kementerian Perindustrian Republik Indonesia yang mencakup lima fokus sektor strategis dan 10 prioritas nasional yang salah satunya terkait dengan percepatan pembangunan infrastruktur digital [3].

Mengingat seluruh desa yang ada di Provinsi Lampung belum sepenuhnya mengimplementasikan inovasi teknologi informasi dan komunikasi dalam pelayanan publik pemerintahan desa [4-6] karena jumlah desa/kelurahan yang begitu besar yang mencapai 2,656 [7], maka dibutuhkan partisipasi aktif dan komitmen dari berbagai pihak, baik institusi publik maupun swasta, industri, pelaku usaha, penyedia teknologi, lembaga riset, kampus, hingga masyarakat untuk mendukung program pemerintah demi mempercepat proses pembangunan $[8,3,9]$ untuk menuju desa yang berjaya, maju, dan mandiri, serta sejahtera [9]. Oleh karena itu, sebagai bentuk partisipasi aktif dari pihak universitas dalam mendukung hal tersebut, maka pengabdian kepada masyarakat dalam rangka hilirisasi inovasi teknologi informasi dan komunikasi untuk menuju independent dan smart village ini dilaksanakan, yang mana hal ini juga sejalan dengan semangat Tujuan Pembangunan Berkelanjutan (TPB) [10] terlebih di masa pandemi COVID-19 ini. Berdasarkan berbagai analisa kebutuhan dan pertimbangan yang dilakukan baik secara formal maupun informal, maka kegiatan ini akan dilakukan di Desa Rukti Endah yang terletak di Kecamatan Seputih Raman, Kabupaten Lampung Tengah. Desa ini memiliki lebih dari 1000 kepala keluarga (KK) dan mayoritas berprofesi sebagai petani dan peternak [11].

Saat ini pemanfaatan berbagai potensi teknologi pada era Revolusi Industri ini, yang juga dikenal dengan istilah Industri 4.0, telah banyak dilakukan [12]. Revolusi Industri 4.0 ini tidak hanya berdampak pada sektor bisnis, pendidikan, dan masyarakat pada umumnya, serta pemerintahan [12] di tingkat pusat saja, namun hingga ke tingkat daerah atau desa. Salah satu program yang terkait dengan penggunaan teknologi yang telah dilakukan di desa adalah digitalisasi desa menuju desa digital. Program ini bertujuan untuk mengurangi kesenjangan arus informasi yang sering terjadi di desa. Melalui digitalisasi desa, inovasi teknologi informasi dan komunikasi (TIK) dapat dimanfaatkan dan diintegrasikan untuk menunjang pelayanan publik dan kegiatan yang berorientasi ekonomi [13] dan teknologi informasi dan digitalisasi desa adalah dua hal yang berkaitan erat yang bisa membawa manfaat bagi masyarakat [14]. Akan tetapi, belum semua desa memanfaatkan teknologi informasi untuk menuju desa digital karena selain potensi, hal ini dapat memunculkan tantangan tersendiri [13]. Desa harus sanggup mengikuti kemajuan teknologi dalam berbagai aspek untuk mendukung program pemerintah "Making Indonesia 4.0" [13] dan harus melibatkan berbagai elemen masyarakat $[8,15]$.

Mengingat kelebihan digitalisasi desa yang sangat besar dibandingkan dengan kekurangannya, banyak desa di Indonesia yang telah mengimplementasikan teknologi informasi dan teknologi guna menunjang pelayanan publik dan administratif pemerintahan desa, misalnya Desa Dermaji di Kabupaten Banyumas [16], Desa Sepakung di Kabupaten Semarang [17], Desa Lamahu di Kabupaten Bone Bolango [18], dan masih banyak lagi. Melihat hal ini, setiap desa dengan berbagai potensi dan letak demografi apapun bisa memanfaatkan kemajuan teknologi untuk menuju desa digital yang mandiri. Di Provinsi Lampung, khususnya, program digitalisasi desa dikemas dalam bentuk program Smart Village [1]. 


\section{METODE}

Peserta yang akan terlibat dalam kegiatan pengabdian kepada masyarakat ini adalah para aparatur desa setempat. Berikut adalah metode pelaksanaan kegiatan ini: 1) Presentasi dan diskusi mengenai desa digital, program smart village, dan tujuan pembangunan berkelanjutan desa; 2) Pengembangan laman resmi desa oleh aparatur desa dan tim pengusul; 3) Praktik dan simulasi melakukan input data dan informasi ke dalam sistem; 4) Praktik dan simulasi melakukan dan melayani warga desa yang membutuhkan pelayanan publik. Kegiatan ini juga akan dievaluasi melalui instrumen sebagai berikut: 1) Tes pengetahuan awal tentang desa digital, program smart village, dan tujuan pembangunan berkelanjutan desa (pre-test); 2) Tes pengetahuan akhir tentang desa digital, program smart village, dan tujuan pembangunan berkelanjutan desa (post-test); 3) Tes praktik dan simulasi penggunaan sistem digital desa melalui observasi oleh tim pengusul; 4) Lembar evaluasi untuk tim yang akan dilakukan oleh para peserta.

Kegiatan pengabdian kepada masyarakat desa binaan ini merupakan kegiatan yang akan dilaksanakan secara bertahap dan berkesinambungan. Oleh karena itu, program ini telah didesain sedemikian rupa sehingga tetap dapat dilanjutkan di tahun-tahun mendatang. Salah satu alasan mengapa kegiatan desa binaan ini harus dilaksanakan secara berkesinambungan adalah tidak memungkinkannya upaya perubahan suatu desa menjadi desa mandiri dan digital secara instan. Diperlukan tahapan-tahapan yang terencana dan terstruktur agar tujuan utama dari program ini dapat tercapai.

Alasan lainnya adalah program pengabdian kepada masyarakat desa binaan ini sesuai dengan semangat program pemerintah, baik di tingkat provinsi maupun pusat. Di Provinsi Lampung, program digitalisasi desa dikemas dalam bentuk program Smart Village [1] dan dibutuhkan partisipasi aktif dan komitmen dari berbagai pihak untuk mendukung program pemerintah ini demi mempercepat proses pembangunan $[8,3,9]$ untuk menuju desa yang berjaya, maju, dan mandiri, serta sejahtera [9].

\section{HASIL DAN PEMBAHASAN}

Kegiatan pengabdian kepada masyarakat yang berjudul "Tujuan Pembangungan Berkelanjutan (TPB): Hilirisasi Inovasi Teknologi Informasi dan Komunikasi menuju Independent dan Smart Village" ini dilaksanakan berdasarkan studi pendahuluan melalui wawancara di tambah dengan melakukan kunjungan langsung di lapangan. Sebagian besar aparat desa masih asing dengan dunia digital sehingga kedepannya perlu dilakukan pendampingan yang intens untuk hal ini. Teknologi menjadi aktivitas baru di masa pandemi yang mana pada pelaksananya di alihkan kepada dunia digital dan dilakukan dengan serba online. Karena pada dasarnya kelebihan digitalisasi desa yang sangat besar dibandingkan dengan kekurangannya, sudah banyak desa di Indonesia yang telah menguunakan teknologi informasi dan teknologi guna menunjang pelayanan publik dan administratif pemerintahan. Hal ini sejalan dengan prinsip-prinsip pelaksanaan tujuan pembangunan berkelanjutan adalah Universality, Integration, dan No One Left Behind (Wahyuningsih, 2016 dalam [19]). Universality memiliki arti bahwa tujuan pembangunan berkelanjutan dilaksanakan oleh negara maju maupun negara berkembang. Integration memiliki arti tujuan pembangunan berkelanjutan dilaksanakan secara terintegrasi antara dimensi sosial, ekonomi dan lingkungan. No One Left Behind memiliki arti bahwa pelaksanaan tujuan pembangunan berkelanjutan harus memberi manfaat bagi semua, terutama yang termarginalkan dan pelaksaan SDGs harus melibatkan berbagai pemangku kepentingan. 
tujuan pembangunan berkelanjutan.

Demi meningkatkan pengetahuan dan wawasan bagi aparatur desa, beberapa langkah diambil oleh tim pengabdian yang meliputi: (1) membuat proposal pengabdian kepada masyarakat yang ditujukan kepada Universitas Lampung, (2) melakukan koordinasi dengan mitra pengabdian, (3) menyusun materi pelatihan, dan (4) melaksanakan kegiatan pelatihan.

\section{Gambaran Peserta dan Proses Pelatihan}

Pengabdian kepada masyarakat yang dilaksanakan di Desa Rukti Endah Kecamatan Seputih Raman Kabupaten Lampung Tengah ini diikuti oleh kepela desa dan aparat desa tersebut. Selama proses pelatihan berlangsung, aparat desa mulai memperlihatkan antusiasnya mendengarkan paparan materi yang disampaikan oleh para narasumber yang dilakukan secara tatap muka untuk memberikan materi kepada peserta dengan diselingi humor membuat ruangan terasa semakin nyaman untuk belajar. Tanya jawab dan diskusi tentang penggunaan aplikasi ini terus muncul yang manakala ada bagian yang dirasa tidak jelas dan kurang dipahami oleh para peserta. Aparat desa juga di berikan kebebasan untuk menyela untuk meminta penjelasan kepada narasumber tentang materi salah satunya adalah berkaitan dengan penggunaan sistem digital desa atau dengan kata lain penggunaan smart village. Hal tersebut bertujuan untuk proses pelatihan menjadi lebih efektif, interaktif, dan efisien. Karena bagi aparat desa maupun masyarakat di Desa Rukti Endah ini adalah hal baru yang perlu dikembangkan karena demi menyelenggarakan program pemerintah tentang desa digital

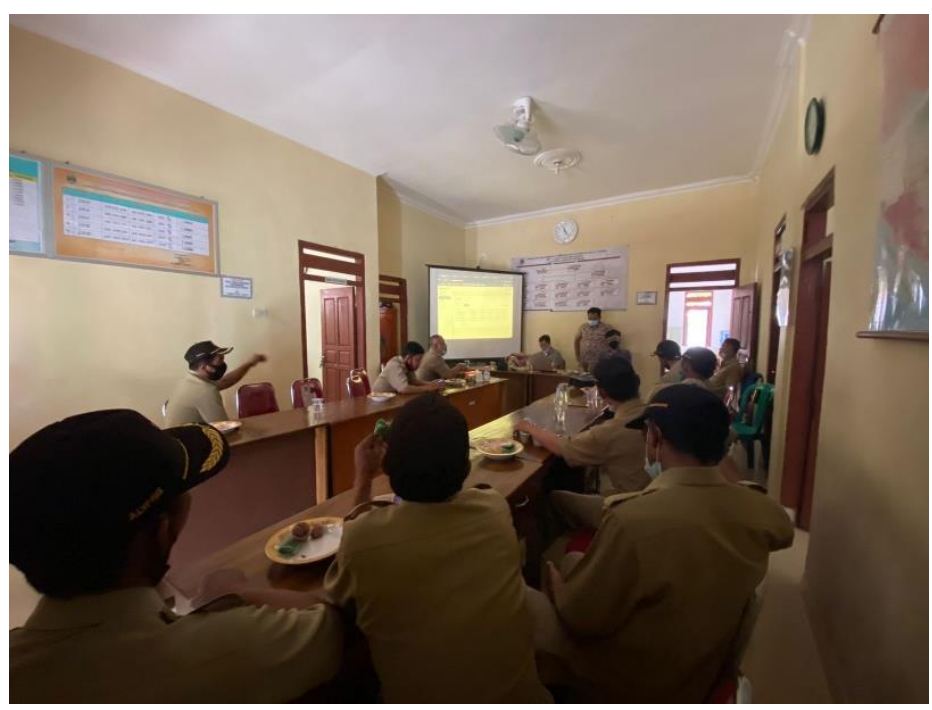

Gambar 1. Suasana awal pelatihan

Peserta nampak lebih antusias mendengarkan materi narasumber ketika sesi praktik dan simulasi tentang digital desa yang akan dibuat akan digunakan nantinya untuk desa tersebut yang diselingi canda dan tawa sehingga membuat suasana interaktif dan menyenangkan. Melihat proses tersebut, dapat dikatakan bahwa para peserta memiliki semangat dan keingintahuan yang tinggi untuk menjalankan desa digital, program smart village, dan tujuan pembangunan berkelanjutan desa. Hal ini karena aparatur desa tidak hanya mendengarkan namun langsung melalukan prantek dan mencoba mengisi data yang menjadi contoh awalan. 


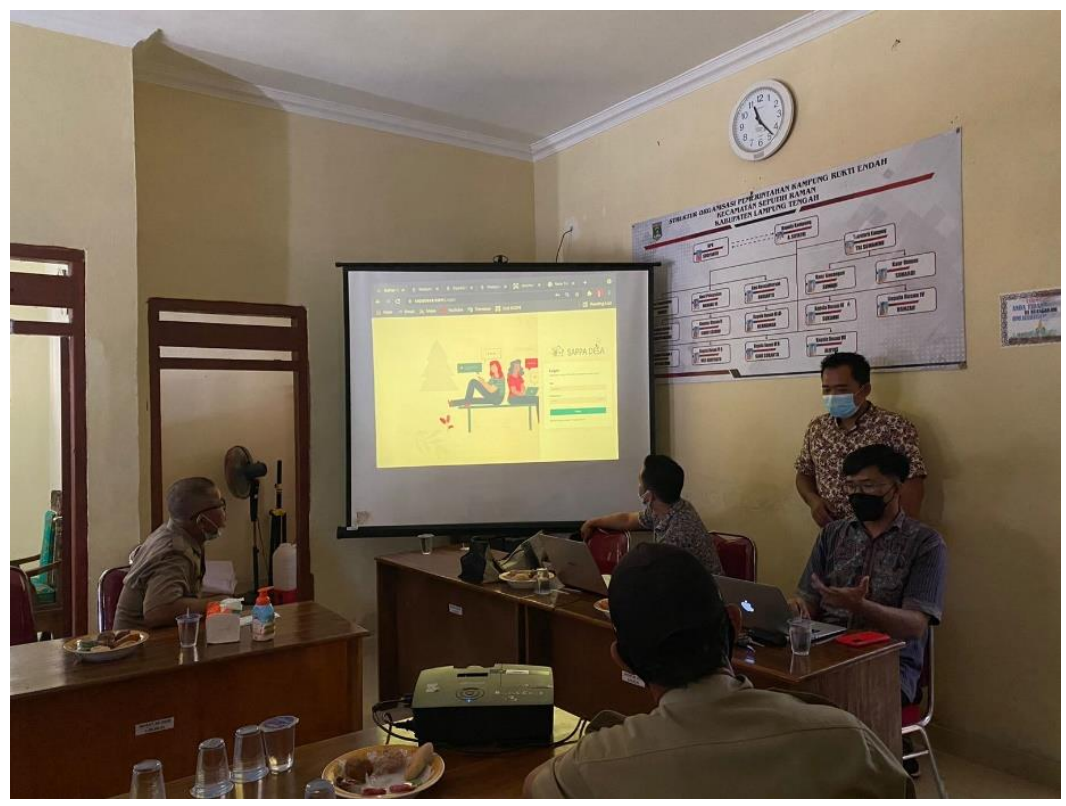

Gambar 2. Suasana saat pelatihan

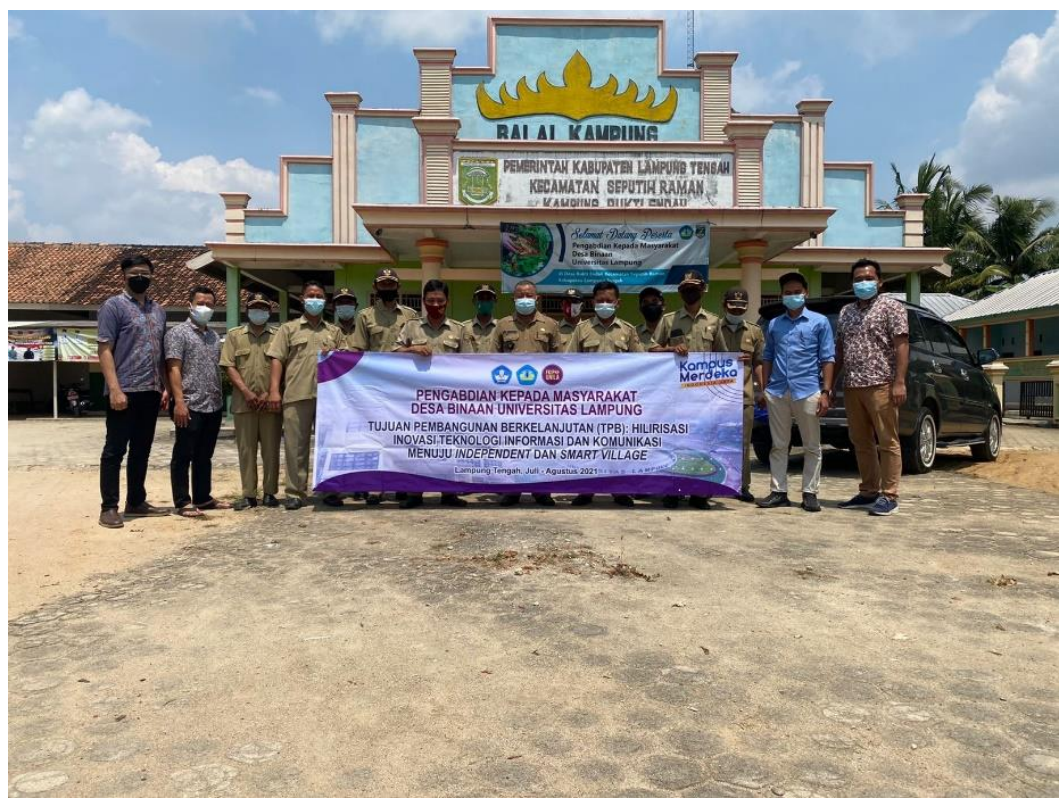

Gambar 3. foto bersama aparatur desa

\section{Hasil Pelatihan}

Desa sebagai kesatuan masyarakat hukum yang homogen tidak bisa disamakan dengan kota dalam adopsi teknologi informasi. Konsep smart city tidak bisa diterapkan di desa dengan mengusung terminologi smart village karena homogenitas masyarakatnya serta lokalitas karateristik dan budaya [20]. Pada kompleks aparatur juga harus dibekali dengan kemampuan dimiliki dalam penggunakan teknologi dari aspek tentang desa digital, program smart village, dan tujuan pembangunan berkelanjutan desa di awal dan akhir pelatihan diberikan angket. Jumlah dari aparatur desa sendiri ada 23 orang kemudian data dapat di lihat pada gambar di bawah ini. 


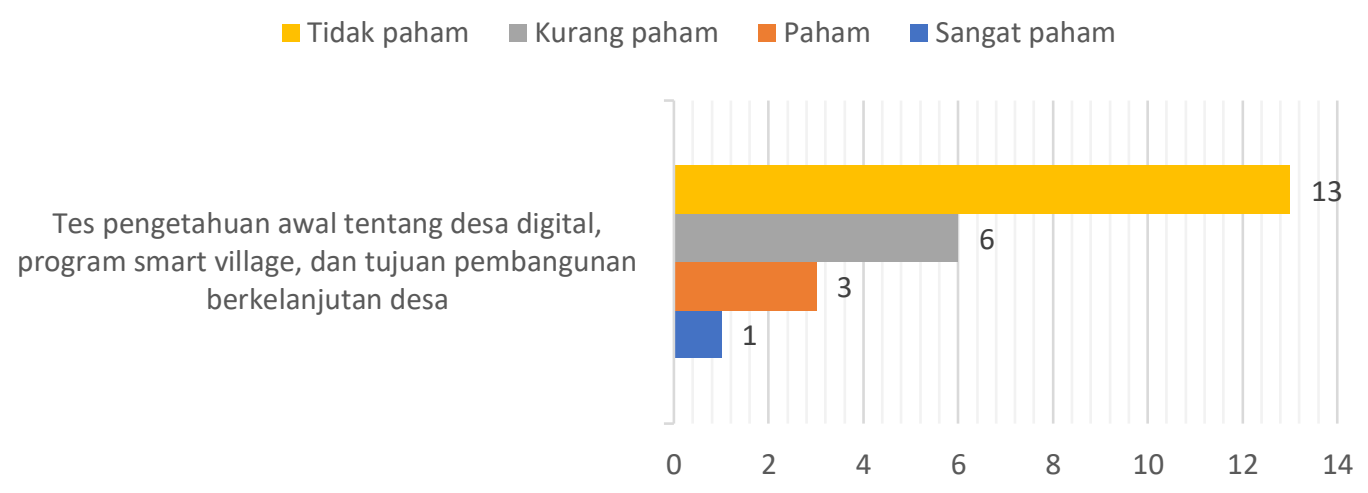

Gambar 4. Hasil tes awal (pre-test) sebelum kegiatan dimulai

Gambar 4 di atas menunjukkan bahwa sebagian besar peserta 13 tidak memahami konsep desa digital, program smart village, dan tujuan pembangunan berkelanjutan, 6 peserta kurang memahami, Peserta yang memahami 2 peserta dan sangat memahami 1 peserta.

Kemudian dari hasil itu para pemateri memberikan pelatihan guna memberikan pemahaman baru tentang desa digital, program smart village, dan tujuan pembangunan berkelanjutan. peserta seiring waktu dapat mulai menangkap dan memahami apa yang disampaikan oleh pemateri. Kemudian di akhir pelatihan hasil pos-test dapat di lihat di bawah ini:

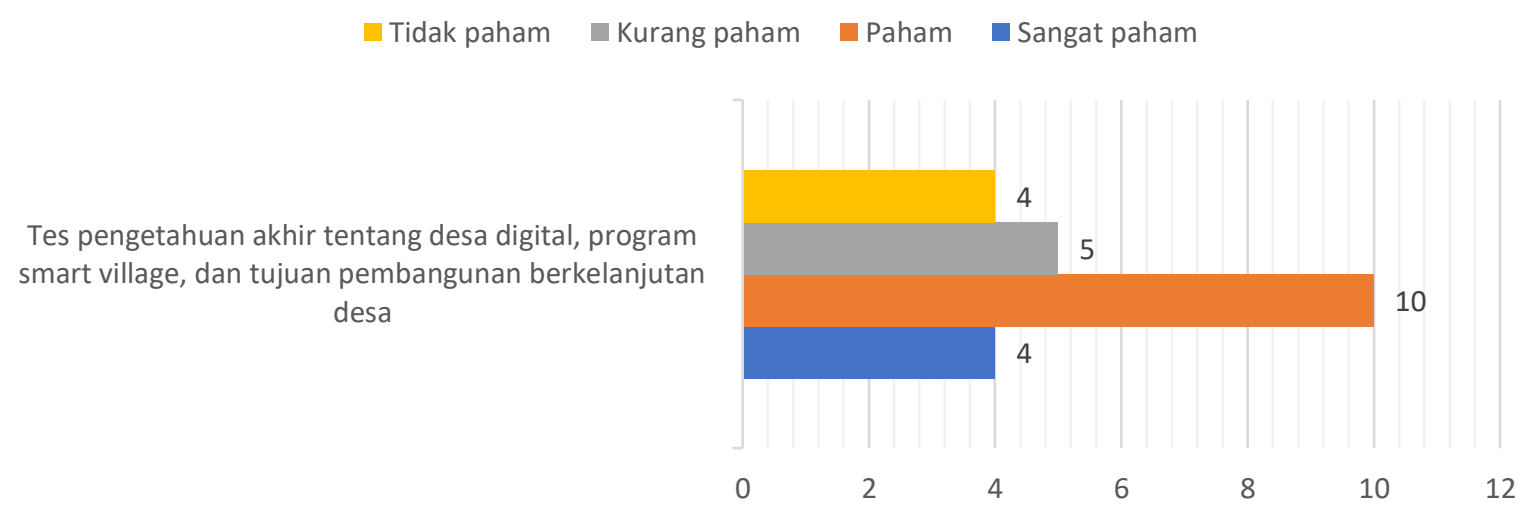

Gambar 5. Hasil tes akhir (post-test) setelah kegiatan

Gambar 5 di atas menunjukkan bahwa sebagian besar peserta sangat memahami sebanyak 4 peserta dan memahami konsep desa digital, program smart village, dan tujuan pembangunan berkelanjutan setelah mengikuti pelatihan sebanyak 10 peserta. Masih terdapat 5 peserta pelatihan yang masih kurang memahami konsep ini dan diikuti oleh 4 peserta yang masih tidak memahami konsep ini. Namun, sebagian besar dari peserta telah 'sangat memahami' dan 'memahami' konsep ini dengan baik.

Pada tahap selanjutnya, para apratur desa dimohon buat membuat ataupun menyiapkan data tentang desa yang nantinya oleh para narasumber kemudian dicontohkan cara pengisan digital desa dengang smart village pada laman web yang sudah di berikan. Aspekaspek Pembuatan desa digital ini kedepan dapat menyelesaikan permasalahan dalam pengurusan berkaitan dengan surat menyurat hal ini menjadikan desa bisa menjadi desa mandiri. Karena secara umum, desa dapat dikatakan desa cerdas apabila desa tersebut secara inovatif menggunakan teknologi informasi untuk mencapai peningkatan kualitas 
hidup, efisiensi dan daya saing dalam aspek ekonomi, sosial dan lingkungan [21].

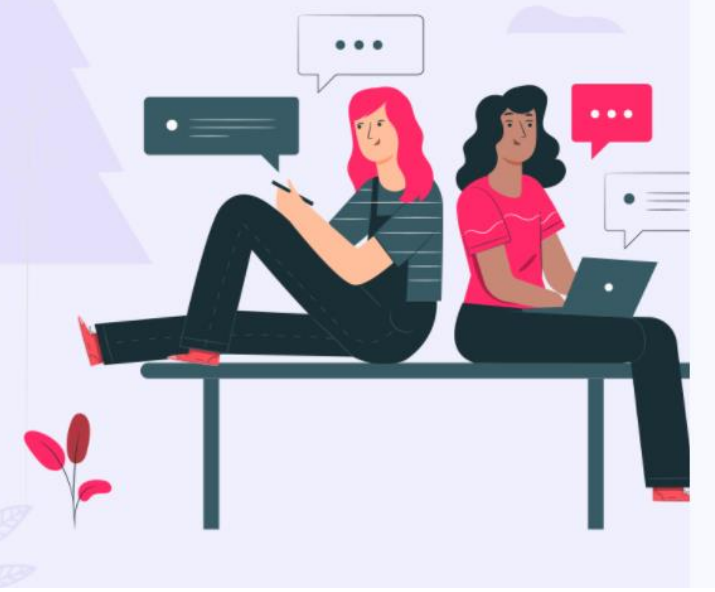

\section{SAPPA DESA}

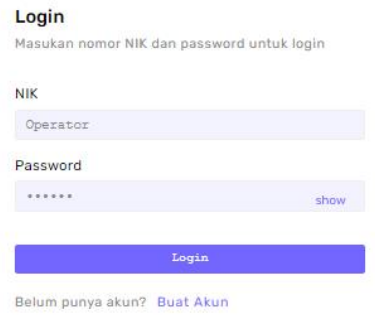

Gambar 6. Laman web desa digital

Gambar 6 Upaya pemanfaatan teknologi informasi dalam pemerintahan desa dapat dilakukan oleh pemerintah desa yakni menjadikan desa menjadi desa digital dengan memanfaatkan smart village. Hal ini sejalan dengan konsep desa pintar yang muncul didasari dari adopsi teknologi informasi untuk mengintegrasikan potensi dan sistem kelembagaan desa, agar menghasilkan manfaat bagi masyarakat pedesaan [22]. Aparatur desa juga harus di bekali dengan kemampuan yang matang dalam penggunaan teknologi sehingga dalam menjalankan desa digital sedikit banyak tidak mengalami kendala.

\section{Pembahasan}

Tujuan dari kegiatan ini adalah untuk: (1.) mengadakan laman resmi desa sebagai langkah awal memasuki era desa digital dan mandiri (smart village); (2) melatih sumber daya manusia desa sehingga mereka mampu meningkatkan digital literacy mereka untuk mendukung program pemerintah di era desa digital dan mandiri (smart village) ini; (3) melakukan digitalisasi berbagai informasi dan data desa melalui laman resmi desa; dan (4) melakukan digitalisasi pelayanan publik pemerintahan desa sehingga berbagai kebutuhan administrasi desa dapat dilakukan dalam genggaman. Perubahan pandangan tentang desa ini diharapkan dapat meningkatkan efektifitas dan tata kelola penyelenggaraan Pemerintahan desa dan meningkatkan kualitas pelayanan publik sehingga dapat meningkatkan kesejahteraan sosial masyarakat desa [23].

Fokus pada diskusi untuk pengabdian kepada masyarakat tahun pertama ini adalah proses pembuatan laman resmi desa yang bisa diakses oleh masyarakat dan dapat digunakan untuk menyampaikan informasi yang ada di desa tersebut. Data desa yang bisa diakses nantinya bisa menjadi trobosan baru bagi aparatur desa guna menjadi desa digital dengan adanya smart village. Kemudian untuk memudahkan pelayanan surat menyurat yang bisa diakses secara luar dari tempat yang berbeda-beda. Melalui konsep desa digital diharapkan dapat mencipatkan desa pintar yang memanfaatkan teknologi sebagai katalisator pembangunan, pendidikan, peluang bisnis lokal, peningkatan dan kesejahteraan seluruh penduduk pedesaan [24]. Desa digital progres untuk kedepannya sangat baik karena dengan adanya smart village diharapkan desa dapat menjadi mandiri dan mampu menjalankannya. Struktur desa juga penting karena menjadikan masyarakat sebagai bagian penting dari pembangunan dan kemajuan desa sehingga hampir semua kebijakan desa 
akan selalu memperhatikan keberadaan masyarakat. Dalam rangka pelaksanaan peran dan fungsi kewenangan aparat desa dan tujuan dasar pelaksanaannya adalah masyarakat.

\section{KESIMPULAN}

Kegiatan pengabdian kepada masyarakat ini telah mencapai tujuan yaitu: (1) meningkatkan wawasan dan pengetahuan tentang pengembangan desa digital yang dapat di akses oleh masyarakat desa; dan (2) memberikan pengetahuan baru bagi desa untuk memudahkan dalam pengurusan surat-menyurat. Kegiatan pengabdian kepada masyarkat pada Desa Rukti Endah Kecamatan Seputih Raman Kabupaten Lampung Tengah, yang sepenuhnya mencerminkan semangat dan keseriusan para peserta untuk mengikuti pengabdian. Melalui kegiatan yang disusun dengan sangat matang yang disesuaikan dengan kebutuhan desa kemudian menjadikan kedepannyan diharapkan pelayanan dapat berjalan dengan baik. Acara ini telah mencapai sejumlah hasil dan meningkatkan kesadaran pemerintah desa akan pentingnya penggunaan teknologi informasi untuk meningkatkan pelayanan publik dalam pemerintahan desa melalu penggunaan smart village. Untuk mencapai tujuan pemerintah desa dalam pembuatan website dan media sosial pemerintah desa.

\section{REFERENCES}

[1] Bappeda Provinsi Lampung. (2019). Smart Village Sebagai Upaya Untuk Meningkatkan Literasi Internet, Layanan Perpustakaan Desa, Digitalisasi, Administrasi Desa, Dan e-Participation.

[2] Pemerintah Provinsi Lampung. (2021). Visi Misi Provinsi Lampung.

[3] Kementerian Perindustrian R.I. (2018). Making Indonesia 4.0. Jakarta.

[4] IDN Times Lampung. (2021). Cerita Pegiat Digitalisasi Kembangkan Program Smart Village di Lampung.

[5] Lampung1 com. (2021). Hanura Desa Digital, Dendi Cek Layanan Adminduk Berbasis Internet.

[6] Pekon Waluyojati. (2021). Pelatihan Digital Marketing Smart Village Pekon Waluyojati.

[7] BPS Provinsi Lampung. (2021). Jumlah Desa/Kelurahan Menurut Kabupaten/Kota Di Provinsi Lampung 2013-2018.

[8] Badri, M. (2016). Pembangunan Pedesaan Berbasis Teknologi Informasi Dan Komunikasi: Studi Pada Gerakan Desa Membangun. Jurnal Risalah 27(2):62-73.

[9] Terasdesa. (2020). 100 Desa Di Lampung Jadi Sasaran Program Smart Village 2021.

[10] SDGs Desa. (2021). SDGs Desa. Retrieved September 17, 2021 (https://sdgsdesa.kemendesa.go.id/sdgsdesa-2/).

[11] Budiyanto, E. (2018). Pemanfaatan Limbah Pertanian Sebagai Pemenuhan Kebutuhan Pakan Ternak Ruminansia di Desa Rukti Endah Kecamatan Seputih Raman Kabupaten Lampung Tengah. Sakai Sambayan Jurnal Pengabdian kepada Masyarakat, 2(3), 109-113.

[12] Hariharasudan, A., \& Kot, S. (2018). A scoping review on Digital English and Education 4.0 for Industry 4.0. Social sciences, 7(11), 227.

[13] Alvaro, R., \& Octavia, E. (2019). Desa Digital: Potensi dan Tantangannya. Buletin APBN, 4(8).

[14] Wijaya, E., Anggraeni, R., \& Bachri, R. (2013). Desa Digital: Peluang untuk Mengoptimalkan Penyebarluasan Peraturan Perundang-undangan di Indonesia. Jurnal Dinamika Hukum, 13(1), 75-88.

[15] Irwansyah. (2020). The social contractual utilitarianism of a digital village in rural Indonesia. TECHNOLOGY IN SOCIETY, 63.

[16] Rokhman, A. (2020, July). Supporting Factors for Digital Village Sustainability in Dermaji Village, 
Banyumas Regency. In Annual International Conference on Social Sciences and Humanities (AICOSH 2020) (pp. 105-107). Atlantis Press.

[17] Agung, R. (2018). Gubernur Jateng Resmikan Desa Digital Sepakung. Suara Merdeka.

[18] Elvina, L. (2020). Canggih! Ini Desa Digital Pertama Di Indonesia. Cerita Indonesia.

[19] Ramadhani, R. W. (2020). Strategi Komunikasi Pembangunan Pemerintah Kabupaten Bojonegoro dalam Menerapkan Nawacita dan Tujuan Pembangunan Berkelanjutan. Jurnal Komunikasi Pembangunan, 18(02), 117-129.

[20] Herdiana, D. (2019). Pengembangan Konsep Smart Village Bagi Desa-Desa di Indonesia (Developing the Smart Village Concept for Indonesian Villages). JURNAL IPTEKKOM (Jurnal Ilmu Pengetahuan \& Teknologi Informasi), 21(1), 1-16.

[21] Ramesh, B. (2018). Concept of Smart Village and it's Impact on Rurbanization. International Journal of Trend in Scientific Reseach and Development, 2, 1948-1950.

[22] Somwanshi, R., Shindepatil, U., Tule, D., Mankar, A., Ingle, N., Rajamanya, G. B. D. V., \& Deshmukh, A. (2016). Study and development of village as a smart village. International Journal of Scientific \& Engineering Research, 7(6), 395-408.

[23] Ansyah, A. B., Wahid, M., \& Hartati, H. (2021). Pendampingan Pengembangan Desa Digital Melalui Komuitas Pemuda Di Desa Pematang Jering Kabupaten Muaro Jambi. RESWARA: Jurnal Pengabdian Kepada Masyarakat, 2(1), 13-19.

[24] Ranade, P., Londhe, S., \& Mishra, A. (2015). Smart villages through information technology-need of emerging India. IPASJ International Journal of Information Technology (IIJIT), 3(7), 1-6. 